\title{
Aeromonas salmonicida Plasmids: Plasmid-directed Synthesis of Proteins in vitro and in Escherichia coli Minicells
}

\author{
By ROBERT J. BELLAND† AND TREVOR J. TRUST* \\ Department of Biochemistry and Microbiology, University of Victoria, Victoria, $B C$, \\ Canada V8W 2 Y2
}

(Received 27 April 1988; revised 12 August 1988; accepted 16 November 1988)

\begin{abstract}
Plasmid DNAs from 25 Aeromonas salmonicida strains (14 'typical' and 11 so-called 'atypical' strains) were analysed using two plasmid isolation techniques in conjunction with restriction enzyme digestion and agarose gel electrophoresis. 'Atypical' strains carried two to four plasmid species, which were different from the plasmids carried by 'typical' strains, and corresponded to isolate source and biotype, suggesting that plasmid content may be a useful epidemiological marker for 'atypical' $A$. salmonicida. The 'typical' group was extremely homogeneous in plasmid content. In addition to a single large $(70-145 \mathrm{~kb})$ structurally related plasmid species, all strains carried a highly conserved group of three low- $M_{\mathrm{r}}$ plasmids (pAsa1, $5.0 \mathrm{~kb} ; \mathrm{pAsa} 2,5.2 \mathrm{~kb}$; pAsa3, $5.4 \mathrm{~kb}$ ). The pAsa plasmids had different restriction maps, and directed the synthesis of four polypeptides when assayed in vitro using a transcription/translation system and $\left[{ }^{35} \mathrm{~S}\right]$ methionine radiolabelling. A partially conserved $6.0 \mathrm{~kb}$ plasmid directed synthesis of an additional polypeptide. Total cellular plasmid DNA from virulent 'typical' strain A. salmonicida A449 was also cloned in Escherichia coli, using the vector pBR322. When analysed using a minicell expression system, 17 plasmid-encoded proteins, ranging in size from 12 to $90 \mathrm{kDa}$, were identified, including two putative exported proteins, and a chloramphenicol acetyltransferase which was encoded by the $145 \mathrm{~kb}$ conserved, non-conjugative, plasmid.
\end{abstract}

\section{INTRODUCTION}

Aeromonas salmonicida is a worldwide pathogen of feral and cultured fish (Trust, 1986). Once thought to infect only salmonids, causing the systemic disease furunculosis, $A$. salmonicida is now commonly isolated from chronic, ulcerative diseases in both salmonid and non-salmonid fish (Bootsma et al., 1977; Evelyn, 1971; Kimura, 1969; Paterson et al., 1980; Shotts et al., 1980; Smith, 1963). Isolates from these slowly progressing diseases produce a markedly different pathogenesis than 'typical' furunculosis strains. They are readily distinguishable by their slow growth, nutritional requirements, and biochemical properties, and are often referred to as the 'atypical' group of A. salmonicida (Ishiguro et al., 1986; McCarthy, 1978; Trust et al., 1980). DNA:DNA reassociation analysis of whole-cell DNA shows two groups of $A$. salmonicida which are related at the genus level, the genetically homogeneous 'typical' $A$. salmonicida subsp. salmonicida, and the genetically diverse 'atypical' strains, which differ from the 'typical' group at the subspecies level. The 'atypical' strains fall into two major taxa: $A$. salmonicida subsp. achromogenes, comprising isolates from salmonid fish, and $A$. salmonicida subsp. nova, comprising isolates from non-salmonid fish (McCarthy, 1978; Belland \& Trust, 1988).

Plasmid carriage by 'typical' strains of $A$. salmonicida has been reported. For example, Toranzo et al. (1983) found that $A$. salmonicida strains carried as many as nine plasmids. They reported a similarity in low- $M_{\mathrm{r}}$ plasmid DNAs but did not characterize these plasmids further. Hackett et al. (1984) also observed a similarity in plasmid profiles, particularly of low- $M_{\mathrm{r}}$ DNAs.

† Present address: Rocky Mountain Laboratories, NIH, NIAID, Hamilton, Montana 59840, USA. 
However, neither study included a broad geographical range of isolates and no functional characteristics were associated with the plasmids reported. Several R-plasmids have also been described in 'typical' A. salmonicida (Aoki et al., 1979, 1986; Hedges et al., 1985). As yet there have been no reports of plasmids in 'atypical' isolates from non-salmonid fish species.

To extend our genetic analysis of this important fish pathogen, we have examined plasmid carriage in a wide variety of $A$. salmonicida strains. Here we compare the plasmid DNA content of typical and atypical strains of $\boldsymbol{A}$. salmonicida, and report the genetic characterization of a highly conserved group of three small plasmids found in all 'typical' isolates examined to date. We also report the expression of low- $M_{\mathrm{r}} A$. salmonicida plasmid DNA in an in vitro transcription/translation system, and the cloning and expression of $A$. salmonicida plasmid DNA in Escherichia coli.

\section{METHODS}

Bacterial strains. A. salmonicida strains used in this study are listed in Tables 1 and 2. 'Typical' $A$. salmonicida strains were grown at $20^{\circ} \mathrm{C}$ on tryptic soy agar (TSA, Difco) or in TS broth (TSB). 'Atypical' $A$. salmonicida strains were cultured at $20^{\circ} \mathrm{C}$ on TSA supplemented with $5 \%$ human blood (TBA), as they have a requirement for added haemin (Ishiguro et al., 1986). All bacterial strains were maintained at $-70^{\circ} \mathrm{C}$ in TSB containing $12 \%(\mathrm{v} / \mathrm{v})$ glycerol.

Plasmid isolation. All isolates were screened using two isolation techniques, that of Portnoy et al. (1981) and that of Kado \& Liu (1981), both essentially as described by Toranzo et al. (1983). For both procedures approximately 50 $\mathrm{mg}$ of cells (wet weight) were harvested from TSA or TBA plates and washed once with TS buffer ( $50 \mathrm{~mm}$ Tris/ $\mathrm{HCl}, 0 \cdot 1 \mathrm{M}-\mathrm{NaCl} ; \mathrm{pH} 8 \cdot 0$ ).

When plasmids were isolated by the method of Portnoy et al. (1981), cells were resuspended in $100 \mu 1$ TS buffer and lysed by the addition of $500 \mu$ lysis buffer $[50 \mathrm{mM}-\mathrm{Tris} / \mathrm{HCl}, 0 \cdot 1 \mathrm{M}-\mathrm{NaCl}, 3 \%(\mathrm{w} / \mathrm{v}) \mathrm{SDS} ; \mathrm{pH} 12 \cdot 4]$ at $37^{\circ} \mathrm{C}$ for $30 \mathrm{~min}$. To this, $30 \mu \mathrm{l}$ neutralization buffer $(2.0 \mathrm{M}-\mathrm{Tris} / \mathrm{HCl} \mathrm{pH} 7.0)$ was added, and the bulk of the chromosomal DNA was precipitated by the addition of $150 \mu \mathrm{l} 5 \mathrm{M}-\mathrm{NaCl}$. After incubation at $0{ }^{\circ} \mathrm{C}$ for at least $4 \mathrm{~h}$, samples were centrifuged at $30000 \mathrm{~g}$ in a microfuge for $10 \mathrm{~min}$. Supernatants were removed to new tubes and plasmid DNA precipitated by the addition of an equal volume of 2-propanol and incubation at $0{ }^{\circ} \mathrm{C}$ for $1 \mathrm{~h}$. The resulting precipitate was collected by centrifugation in a microfuge at $15000 \mathrm{~g}$ for $5 \mathrm{~min}$. Precipitated DNA was suspended in TE buffer (10 mM-Tris/ $\mathrm{HCl}, 1 \mathrm{~mm}$-EDTA; $\mathrm{pH} \mathrm{7.6)}$ in preparation for agarose gel electrophoresis.

To extract plasmid DNA by the technique of Kado \& Liu (1981), washed cells were resuspended in $200 \mu 1$ lysis buffer $(50 \mathrm{~mm}$-Tris/acetate, $3 \% \mathrm{SDS} ; \mathrm{pH} 12 \cdot 4)$ and incubated at $95^{\circ} \mathrm{C}$ for $5 \mathrm{~min}$. Following a brief extraction with an equal volume of phenol/chloroform $(1: 1, \mathrm{v} / \mathrm{v})$ the emulsion was separated by centrifugation. The aqueous phase was removed to a new tube for agarose gel electrophoresis.

Plasmid DNA for restriction analysis, cloning, and in vitro expression experiments was purified by scaling up the Kado and Liu extraction technique (using sodium lauroyl sarcosinate in place of SDS) to $2 \mathrm{~g}$ cells and $25 \mathrm{ml}$ lysis buffer. Phenol/chloroform-extracted plasmid-containing lysates were made to a density of $1.55 \mathrm{~g} \mathrm{ml}^{-1}$ by the addition of solid $\mathrm{CsCl}$, and ethidium bromide was added to a final concentration of $600 \mu \mathrm{g} \mathrm{ml}^{-1}$. Gradients were centrifuged to equilibrium at $134000 \mathrm{~g}$ for $36 \mathrm{~h}$.

Plasmid DNA and restriction enzyme digestions of plasmid DNA were analysed by horizontal agarose gel electrophoresis. Voltage gradients of $12 \mathrm{~V} \mathrm{~cm}^{-1}$ were used, except in the case of 'typical' isolates, where it was necessary to use much lower gradients $\left(2 \mathrm{~V} \mathrm{~cm}^{-1}\right)$ to resolve plasmid DNA in the $5 \cdot 0-5 \cdot 4 \mathrm{~kb}$ range. DNA was visualized by soaking in a solution of $0.5 \mathrm{mg}$ ethidium bromide $\mathrm{ml}^{-1}$ for $30 \mathrm{~min}$ and viewing over a UV transilluminator. Photographs were made using an MP-4 camera head and Polaroid land film (type 665/667). Plasmid standards used in the study were pBR322 (4.36 kb), RSF1010 (13.2 kb), Sa (38 kb), RP4 (51.7 kb), R1 (92.7 $\mathrm{kb})$ and R27 (170 kb).

Conjugal transfer of $R$ plasmids. R-plasmids in $A$. salmonicida strains were detected by conjugal mating procedures (Curtiss, 1981) on solid media at $20^{\circ} \mathrm{C}$. Overnight broth cultures of E. coli HB101 were mixed with $48 \mathrm{~h}$ broth cultures of $A$. salmonicida and aseptically filtered onto sterile $25 \mathrm{~mm}$ membrane filters (Micron Sep Inc.) with a $45 \mu \mathrm{m}$ pore size. Membrane filters containing the mating mixtures were incubated on TSA plates for $3 \mathrm{~h}$ at $20^{\circ} \mathrm{C}$, after which suitable dilutions were plated on TSA supplemented with tetracycline $\left(15 \mathrm{mg} \mathrm{ml}^{-1}\right)$, chloramphenicol $\left(30 \mathrm{mg} \mathrm{m}^{-1}\right)$ or streptomycin $\left(50 \mathrm{mg} \mathrm{ml}^{-1}\right)$ and incubated at $37^{\circ} \mathrm{C}$ overnight to counterselect $A$. salmonicida (no growth at $37^{\circ} \mathrm{C}$ ). Donor and recipient controls were similarly treated.

Plasmid DNA cloning. Total plasmid DNA from 'typical' strain A449 was isolated by the scaled-up Kado and Liu extraction technique described above. After purification by $\mathrm{CsCl}$ /ethidium bromide equilibrium density gradient centrifugation, the plasmid DNA was digested with BamHI (Pharmacia) and analysed by agarose gel electrophoresis. Digested plasmid DNA was then ligated into BamHI-cleaved and dephosphorylated pBR322 and 
transformed into the minicell-producing $E$. coli strain GK403 (thr leu thi lac Y gal minAB $\mathrm{Tc}^{\mathrm{s}} \mathrm{rps}$ ). Transformants were selected on agar supplemented with ampicillin and tetracycline, and putative recombinants identified by their Apr $\mathrm{Tc}^{\mathrm{s}}$ phenotype were screened for the presence of inserts using the rapid plasmid screening technique of Portnoy et al. (1981) and restriction analysis with BamHI. The presence of cloned $A$. salmonicida plasmid DNA sequences in recombinant plasmids was confirmed by dot-blot hybridization (Maniatis et al., 1982) using ${ }^{32} \mathrm{P}$ radiolabelled total $A$. salmonicida A449 plasmid DNA as a probe.

In vitro labelling of piasmid-encoded proteins. Purified plasmid DNA was dialysed against Tris/acetate buffer ( 10 $\mathrm{mM}, \mathrm{pH} 8.0$ ), and adjusted to $0.5 \mathrm{mg} \mathrm{ml}^{-1}$. Plasmid-DNA-directed protein synthesis was done using a commercially available (Enzo-Biochem) lysate prepared according to a modification of the procedure of Yang $e t$ al. (1980). $\left[{ }^{35}\right.$ S]Methionine was used for radiolabelling according to the instructions of the manufacturer, and plasmid-specified proteins were identified by SDS-PAGE (Laemmli, 1970) and autoradiography.

Minicells from E. coli GK403 derivatives, harbouring recombinant plasmids, were isolated following growth in rich medium, and purified by differential centrifugation in linear sucrose density gradients, as described by Dougan et al. (1983). Minicells, suspended to an $\mathrm{OD}_{600}$ of 0.5 in $\mathrm{M} 9$ salts supplemented with $0.2 \%$ glucose and vitamin Bl $\left(0.5 \mathrm{mg} \mathrm{ml}^{-1}\right)$, in the presence and absence of $10 \%(\mathrm{v} / \mathrm{v})$ ethanol (Halegoua \& Inouye, 1979; Palva et al., 1981 ; Dougan et al. 1983), were labelled in the presence of $0.25 \%$ methionine assay medium (Difco) with $5.6 \mathrm{mCi}$ $\left.(207 \mathrm{MBq}){ }^{35} \mathrm{~S}\right]$ methionine $(\mathrm{NEN})$ at $37^{\circ} \mathrm{C}$ for $1 \mathrm{~h}$, following a $30 \mathrm{~min}$ preincubation. Labelled minicells were harvested by centrifugation in a microfuge and suspended in a solubilization buffer (Tris/ $\mathrm{HCl}, 60 \mathrm{~mm}$; glycerol, $1 \%$; 2-mercaptoethanol, $5 \%$, SDS, 3\%; bromophenol blue, $0.01 \%$ pH 6.8) before boiling for $10 \mathrm{~min}$. Samples were resolved on SDS-PAGE gels $(12.5 \%$, w/v, acrylamide) by the procedure of Laemmli (1970) and the gels, following a rapid stain, fix, and destain, were exposed directly to X-AR5 film (Kodak Eastman Co.) for autoradiography.

Acetyltransferase activity and cell fractionation. Acetyltransferase activity was assayed using the spectrophotometric procedure of Shaw (1975); cell inner and outer membrane, periplasmic and cytosol fractions were prepared essentially as described by Filip et al. (1973) and Willis et al. (1974).

\section{RESULTS}

\section{Plasmid carriage}

Plasmid DNA from each A. salmonicida strain was isolated by the techniques of both Kado \& Liu (1981) and Portnoy et al. (1981) at least twice, and only strains giving identical patterns on each occasion are reported here. The yield of plasmid DNA from $A$. salmonicida varied according to the purification procedure employed. In general, the method of Kado \& Liu (1981) was the more satisfactory isolation procedure as it consistently gave both high- $(>70 \mathrm{~kb})$ and low- $M_{\mathrm{r}}$ plasmids. Lysing cells at $95^{\circ} \mathrm{C}$ for $3-5$ min gave the best yields of DNA; however, strains varied considerably in their susceptibility to lysis, probably in part due to the presence or absence of the surface protein array (A-layer) (Udey \& Fryer, 1978; Kay et al., 1981; Ishiguro et al., 1981). High- $M_{\mathrm{r}}$ plasmids in $A$. salmonicida were especially difficult to isolate in large quantities, appearing to be particularly susceptible to shearing during the isolation procedures. The method of Portnoy et al. (1981) frequently gave a poor yield of high- $M_{\mathrm{r}}$ plasmid DNA. Indeed a slight alteration of the method (i.e. incubating cells in lysis buffer for $15 \min$ at $0{ }^{\circ} \mathrm{C}$ ) allowed the selective isolation of low- $M_{\mathrm{r}}$ plasmid DNA.

A total of 25 strains of $A$. salmonicida were examined: 14 'typical' and 11 'atypical' strains. All contained at least two plasmids, and plasmid sizes ranged from 3.5 to $150 \mathrm{~kb}$ as estimated by comparison with standard plasmid DNA isolated by the same techniques. Electrophoretic patterns of plasmid DNA from 'typical' strains were remarkably similar. 'Typical' strains of $\boldsymbol{A}$. salmonicida contained from four to seven plasmid species, ranging from 3.5 to $145 \mathrm{~kb}$ in size, and all 14 strains possessed a group of three low- $M_{\mathrm{r}}$ plasmids of $5 \cdot 0,5 \cdot 2$ and $5 \cdot 4 \mathrm{~kb}$ (Table 1 ). Ten of the 14 'typical' strains had a fourth low- $M_{\mathrm{r}}$ plasmid of $6.0 \mathrm{~kb}$. Plasmids in Table 1 (columns A-F) had indistinguishable or very similar restriction digestion fingerprint patterns using $B a m H I$. R-plasmids which could be conjugally transferred to $E$. coli were found in $4 / 14$ strains. Each of these four strains contained conjugative plasmids which coded for $\mathrm{Tc}^{\mathrm{r}}$, and strain A473 contained two R-plasmids, the larger of which was transferable to $E$. coli and coded for resistance to chloramphenicol and streptomycin.

Electrophoretic profiles of plasmid DNA isolated from 'atypical' strains, and restriction digestion fingerprint patterns using BamHI, showed that the plasmids from 'atypical' strains 
Table 1. Plasmid carriage in 'typical' A. salmonicida isolates

\begin{tabular}{|c|c|c|c|c|c|c|c|c|c|}
\hline \multirow[b]{2}{*}{ Strain } & \multirow[b]{2}{*}{ Source } & \multirow[b]{2}{*}{ A-layer } & \multicolumn{7}{|c|}{ Plasmid size $(\mathrm{kb})^{*}$} \\
\hline & & & A & B & $\mathrm{C}$ & $\mathrm{D}$ & $\mathrm{E}$ & F & G \\
\hline A251 & NCMB 1102, Atlantic salmon, Scotland & + & $5 \cdot 0$ & $5 \cdot 2$ & $5 \cdot 4$ & $6 \cdot 0$ & & 120 & \\
\hline A362 & Sea trout, England & + & $5 \cdot 0$ & $5 \cdot 2$ & $5 \cdot 4$ & $6 \cdot 0$ & & 75 & \\
\hline A437 & Sockeye salmon, BC, Canada & + & $5 \cdot 0$ & $5 \cdot 2$ & $5 \cdot 4$ & $6 \cdot 0$ & & 130 & \\
\hline A438 & Coho salmon, BC, Canada & - & $5 \cdot 0$ & $5 \cdot 2$ & $5 \cdot 4$ & $6 \cdot 0$ & & 130 & \\
\hline A440 & ATCC 14174 , Brook trout, USA & - & $5 \cdot 0$ & $5 \cdot 2$ & $5 \cdot 4$ & & $28(\mathrm{R})$ & 120 & \\
\hline A449 & Brown trout, Eure, France & + & $5 \cdot 0$ & $5 \cdot 2$ & $5 \cdot 4$ & & & 145 & \\
\hline A450 & Brown trout, Tarn, France & + & $5 \cdot 0$ & $5 \cdot 2$ & $5 \cdot 4$ & & & 145 & \\
\hline A451 & Rainbow trout, Manch, France & + & $5 \cdot 0$ & $5 \cdot 2$ & $5 \cdot 4$ & $6 \cdot 0$ & & 135 & \\
\hline A470 & Rainbow trout, Wash. St., USA & + & $5 \cdot 0$ & $5 \cdot 2$ & $5 \cdot 4$ & 6.0 & $28(\mathrm{R})$ & 145 & \\
\hline A473 & Coho salmon, Wash. St., USA & - & $5 \cdot 0$ & $5 \cdot 2$ & $5 \cdot 4$ & $6 \cdot 0$ & $26(\mathrm{R})$ & 135 & 95(R) \\
\hline A482 & Steelhead trout, BC, Canada & + & $5 \cdot 0$ & $5 \cdot 2$ & $5 \cdot 4$ & & & 70 & 12 \\
\hline A488 & Brook trout, New Hamp., USA & + & $5 \cdot 0$ & $5 \cdot 2$ & $5 \cdot 4$ & $6 \cdot 0$ & & 145 & \\
\hline A494 & Coho salmon, Ore., USA & + & $5 \cdot 0$ & $5 \cdot 2$ & $5 \cdot 4$ & $6 \cdot 0$ & & 120 & $3 \cdot 5$ \\
\hline A 500 & Atlantic salmon, Mass., USA & + & $5 \cdot 0$ & $5 \cdot 2$ & $5 \cdot 4$ & $6 \cdot 0$ & $30(\mathrm{R})$ & 120 & \\
\hline
\end{tabular}

* Plasmids in columns A-F show restriction fragment fingerprint similarities with the column. (R) indicates that these plasmids carry antibiotic resistance determinants that have been conjugally transferred to $E$. coli (resistances described in text).

Table 2. Plasmid carriage in 'atypical' A. salmonicida isolates

\begin{tabular}{|c|c|c|c|c|c|c|}
\hline \multirow[b]{2}{*}{ Strain } & \multirow[b]{2}{*}{ Source } & \multirow[b]{2}{*}{ A-layer } & \multicolumn{4}{|c|}{ Plasmid size $(\mathrm{kb})^{*}$} \\
\hline & & & A & B & $\mathrm{C}$ & $\mathrm{D}$ \\
\hline A400 & Goldfish, Boolara, Australia & + & $5 \cdot 8^{a}$ & $38^{b}$ & $60^{c}$ & \\
\hline A406 & Goldfish, Boolara, Australia & - & $5 \cdot 8^{a}$ & $38^{b}$ & $60^{c}$ & $150^{d}$ \\
\hline A419 & Goldfish, Ark., USA & + & $5 \cdot 8^{a}$ & $38^{b}$ & $60^{\circ}$ & \\
\hline A491 & Goldfish, Md., USA & + & $5 \cdot 8^{a}$ & $38^{b}$ & $60^{c}$ & $140^{d}$ \\
\hline A206 & Masou, Japan & - & $4 \cdot 0$ & 70 & & \\
\hline A460 & Atlantic salmon, NS, Canada & + & 18 & 36 & 48 & \\
\hline A452 & European carp, Netherlands & + & 35 & 60 & 80 & \\
\hline A475 & European carp, Norway & + & $4 \cdot 2^{e}$ & $4 \cdot 4^{f}$ & 55 & 140 \\
\hline A436 & Sablefish, Nanaimo, Canada & - & $4 \cdot 2^{e}$ & $4 \cdot 4 f$ & & \\
\hline A479 & European carp, Denmark & + & $8 \cdot 4^{9}$ & $55^{h}$ & & \\
\hline A 480 & European carp, Netherlands & + & $8 \cdot 4^{g}$ & $60^{h}$ & & \\
\hline
\end{tabular}

* Plasmids with the same superscripts $(a-h)$ show restriction fragment fingerprint similarities.

differed significantly from the 'typical' strains, and also differed within the 'atypical' group itself. Plasmids isolated from 11 'atypical' strains are listed in Table 2. All 'atypical' strains examined possessed from two to four plasmid species, ranging in size from 4.0 to $150 \mathrm{~kb}$. No detectable similarity in restriction fragment patterns was seen through the entire group of 'atypical' plasmids, although certain sub-groupings were apparent in electrophoretic plasmid profiles. Strains A400, A406, A419 and A491 had three plasmids of 5.8, 38 and $60 \mathrm{~kb}$, two isolates (A475 and A436) had two small plasmids of 4.2 and $4.4 \mathrm{~kb}$, while another two strains (A479 and A480) had a small (8.4) and an intermediate size plasmid (55-60 kb).

\section{Small, conserved plasmid DNAs of 'typical' A. salmonicida}

Small plasmid DNAs were selectively purified by incubating cells in Portnoy lysis buffer for 15 min at $0{ }^{\circ} \mathrm{C}$ followed by $\mathrm{CsCl}$ equilibrium density gradient centrifugation. The three small plasmids of 'typical' virulent strain A449 (pAsal, 5.0 kb; pAsa2, $5 \cdot 2 \mathrm{~kb}$; pAsa3, $5 \cdot 4 \mathrm{~kb}$ ) were mapped simultaneously using a series of single, double and triple restriction enzyme digests. The mapping was confirmed following the cloning in pUC18 of: pAsal as a single $5 \cdot 0 \mathrm{~kb}$ BamHI fragment; a $4.2 \mathrm{~kb}$ HindIII/BglII fragment of pAsa2; and a $4 \cdot 0 \mathrm{~kb} B g / \mathrm{II}$ fragment of pAsa3. 


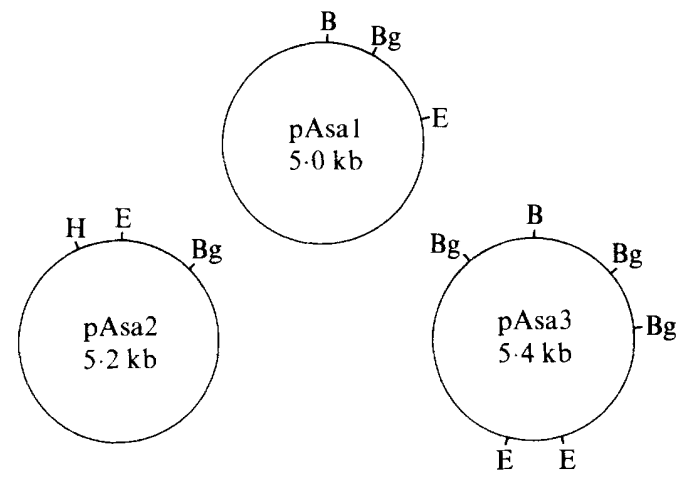

Fig. 1. Restriction maps of conserved low- $M_{\mathrm{r}}$ plasmids pAsa1, pAsa2 and pAsa 3 from 'typical' $A$. salmonicida strain A449. B, BamHI; Bg, BglII; E, EcoRI; H, HindIII.

Each pAsa plasmid exhibited a unique restriction map (Fig. 1). The synthesis of proteins directed by these three conserved low $M_{\mathrm{r}}$ plasmids was examined using a commercially available transcription/translation lysate by labelling with $\left[{ }^{35} \mathrm{~S}\right]$ methionine. A pAsal-3 plasmid DNA mixture from strain A449 directed the synthesis of four proteins, of $M_{\mathrm{r}} 25500,26700$, 28000 and 32300 (Fig. $2 a$, lane 1, open circles). Proteins of the same apparent $M_{\mathrm{r}}$ were seen when low- $M_{\mathrm{r}}$ plasmid DNA from strains A251, A451 and A488 was used in the transcription/translation system. Plasmid DNA from these three strains also contained the $6.0 \mathrm{~kb}$ plasmid and produced additional proteins of $M_{\mathrm{r}} 33100$ and 34500 (Fig. 2, filled circles).

To determine coding differences between the low- $M_{\mathrm{r}}$ plasmids of the 'typical' and 'atypical' strains, the proteins specified by the $5.8 \mathrm{~kb}$ plasmids of 'atypical' strains A400 and A419, and the $8.4 \mathrm{~kb}$ plasmid of 'atypical' strain A479, were also examined. The $5.8 \mathrm{~kb}$ plasmid of strains A400 and A419 coded for proteins of $M_{\mathrm{r}} 14000,17200,30000,32500$ and 34000 , and the $8.4 \mathrm{~kb}$ plasmid of strain A479 coded for proteins of $M_{\mathrm{r}} 14200,30100$ and 33300 (Fig. $2 b$ ).

\section{Cloning and expression of $A$. salmonicida plasmid DNA in minicells}

The expression of cloned $A$. salmonicida plasmid DNA from 'typical' virulent strain A449 was examined in minicells. In addition to the three small plasmids, pAsal, 2 and 3, strain A449 carried large plasmid pAsa4 of about $145 \mathrm{~kb}$. Strain A449 was resistant to chloramphenicol, tetracycline and streptomycin (MICs about 250,250 , and $300 \mathrm{mg} \mathrm{ml}^{-1}$ respectively), but none of these resistances could be conjugally transferred or transformed into $E$. coli using plasmid DNA and standard techniques.

Following isolation, digestion, and ligation of total A449 cellular plasmid DNA to the vector pBR322, recombinant Amp ${ }^{r} \mathrm{Tet}^{\mathrm{s}}$ isolates were screened for the presence of inserts using a rapid plasmid isolation technique and dot-blot hybridization using ${ }^{32} \mathrm{P}$-radiolabelled $A$. salmonicida A449 plasmid DNA as probe to confirm that the inserts were $A$. salmonicida plasmid DNA (Fig. $3 a$ ). In Fig. 3(a) the numbered fragments correspond to $A$. salmonicida plasmid DNA fragments cloned into pBR322 (plasmid constructs pEB1-15), and reacted with radiolabelled A449 plasmid DNA (Fig. $3 b$ ). Band 10 in Fig. $3(a)$ is a $5.2 \mathrm{~kb}$ plasmid (pAsa2) that has no BamHI site and was therefore not represented in the plasmid library. Best estimates indicated that approximately $75 \mathrm{~kb}$ of an estimated $160.6 \mathrm{~kb}$ of A449 plasmid DNA, or approximately $47 \%$ of the plasmid genome, was cloned in this experiment. The disparity between the total amount of plasmid DNA available and that accounted for by agarose gel electrophoresis following digestion is probably due to the failure to separate fragments of similar size (e.g. it is likely that one or more of the bands 1-4 in Fig. 3(a) contain comigrating Bam HI fragments) and to the generation of low- $M_{\mathrm{r}}$ fragments that were too small to be retained in the gel.

The expression of cloned plasmid DNA from each recombinant strain was analysed in $\left.{ }^{[35} \mathrm{S}\right]$ methionine-radiolabelled $E$. coli minicells in the presence or absence of $10 \%$ ethanol, a 


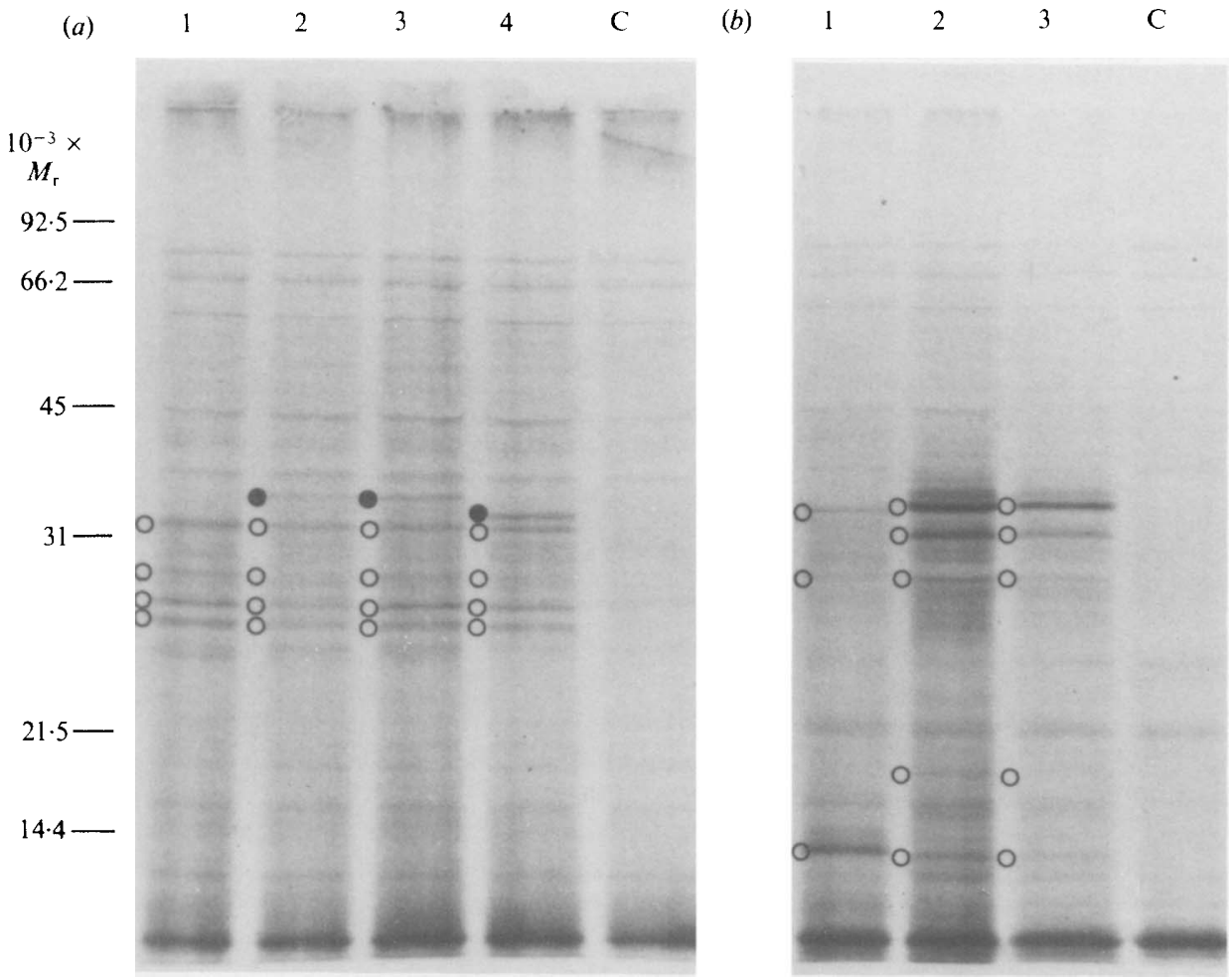

Fig. 2. Autoradiographs of $\left[{ }^{35} \mathrm{~S}\right]$ methionine-radiolabelled plasmid-DNA-encoded proteins resolved on $12.5 \%$ SDS-PAGE gels. Low- $M_{\mathrm{r}}$ plasmids from 'typical' $A$. salmonicida strains A449, A451, A488 and A251 were used in part (a), lanes 1-4 respectively. Low- $M_{\mathrm{r}}$ plasmids from 'atypical' strains A479, A400 and A419 were used in part (b), lanes 1-3 respectively. Lanes $C$ in both $(a)$ and $(b)$ represent controls in which TE buffer was added to the lysate in place of plasmid DNA. Standard proteins were phosphorylase $b$ (top), bovine serum albumin, ovalbumin, carbonic anhydrase, soybean trypsin inhibitor and lysozyme; their sizes are given on the left

Table 3. Recombinant plasmids containing A. salmonicida plasmid DNA directing synthesis of $\left[{ }^{35}\right.$ S]methionine-labelled proteins

\begin{tabular}{|c|c|c|c|c|c|c|}
\hline Plasmid & $\begin{array}{l}\text { Insert size } \\
\quad(\mathrm{kb})\end{array}$ & \multicolumn{5}{|c|}{$\begin{array}{l}10^{-3} \times M_{\mathrm{r}} \text { of proteins } \\
\text { expressed in minicells }\end{array}$} \\
\hline pEB1 & 15.0 & 23 & 90 & & & \\
\hline $\mathrm{pEB} 2$ & $12 \cdot 0$ & 12 & 14 & $15.8^{*}$ & 60 & $63^{*}$ \\
\hline $\mathrm{pEB} 3$ & 7.5 & 21 & 25 & & & \\
\hline pEB4 & $5 \cdot 0$ & 28 & 68 & & & \\
\hline pEB5 & $4 \cdot 8$ & & & & & \\
\hline pEB6 & $4 \cdot 0$ & 15 & 42 & & & \\
\hline $\mathrm{pEB} 7$ & $3 \cdot 8$ & 14.5 & & & & \\
\hline pEB8 & $3 \cdot 7$ & $13 \cdot 5$ & & & & \\
\hline pEB 9 & $3 \cdot 0$ & & & & & \\
\hline pEB 10 & $2 \cdot 1$ & 58 & & & & \\
\hline pEB 11 & $2 \cdot 0$ & & & & & \\
\hline $\mathrm{pEB} 12$ & 1.9 & & & & & \\
\hline $\mathrm{pEB} 13$ & $1 \cdot 5$ & & & & & \\
\hline pEB 14 & 1.35 & 20 & & & & \\
\hline pEB15 & 1.2 & & & & & \\
\hline
\end{tabular}

* These proteins are presumed to be unprocessed export proteins. 


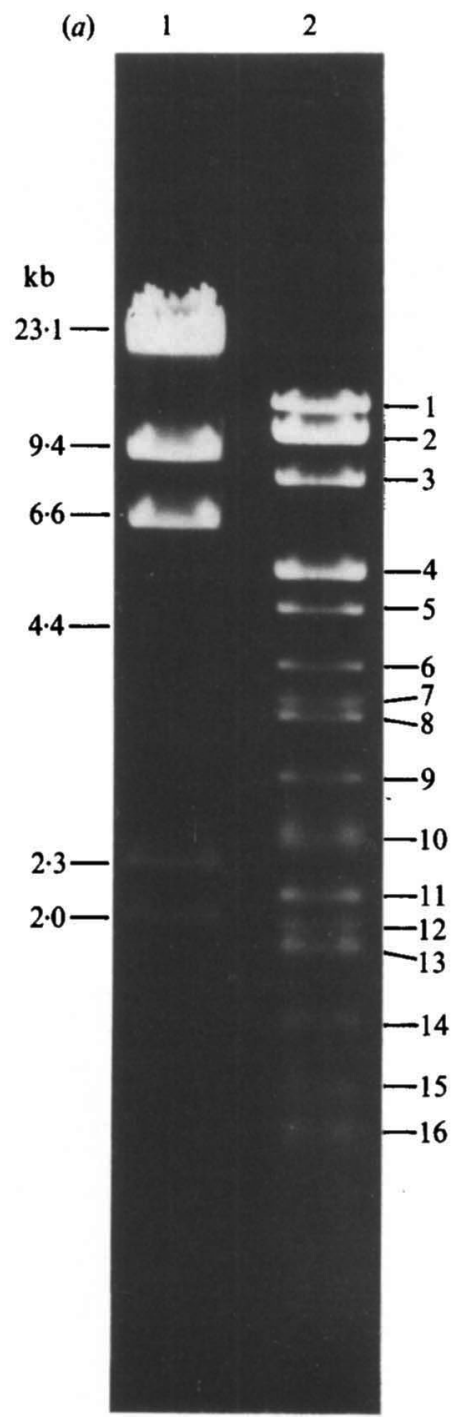

(b)

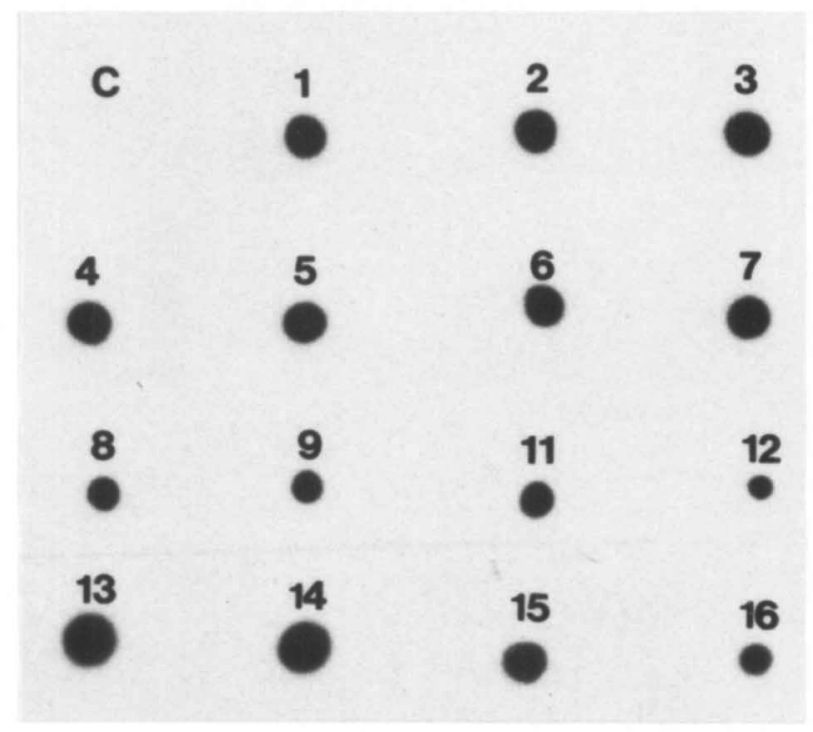

Fig. 3. (a) BamHI-digested plasmid DNA from A. salmonicida strain A449 (lane 2) resolved on a $0 \cdot 8 \%$ agarose gel adjacent to DNA $M_{\mathrm{r}}$ standards [ $\lambda$ DNA cleaved with HindIII; fragment sizes are indicated (fragments of 0.56 and $0.13 \mathrm{~kb}$ are not visible)]. Numbered DNA fragments have been cloned into pBR322 with the exception of 10 , which represents a small plasmid (pAsa2) with no BamHI site. Numbers 1-9 indicate recombinant plasmids pEB1-9, and numbers $11-16$ plasmids pEB10-15. (b) Recombinant plasmids $[0.5 \mu \mathrm{g}$, numbered as in $(a)]$ dot-blotted onto Gene Screen Plus and probed with ${ }^{32}$ P-radiolabelled A449 plasmid DNA. Control plasmid DNA (pBR322) is in the position labelled ' $c$ '.

procedure known to prevent the removal of signal sequences from many exported proteins (Halegoua \& Inouye, 1979; Palva et al., 1981; Dougan et al., 1983). A total of 17 proteins (a conservative estimate based on SDS-PAGE and autoradiography), ranging in size from $M_{\mathrm{r}}$ 12000 to $M_{\mathrm{r}} 90000$ were expressed from $A$. salmonicida plasmid DNA (Fig. 4, Table 3). A single recombinant, pEB2, expressed two putative exported proteins (Fig. 4, lane $6+/-$ ), one with a mature $M_{\mathrm{r}}$ of 14000 (unprocessed $M_{\mathrm{r}} 15800$ ) and the other with a mature $M_{\mathrm{r}}$ of 60000 (unprocessed $M_{\mathrm{r}} 63000$ ). The pBR322 control reaction (Fig. 4, lane $1+/-$ ) showed that the processing of pre- $\beta$-lactamase (open triangles) to mature $\beta$-lactamase (closed triangle) was 


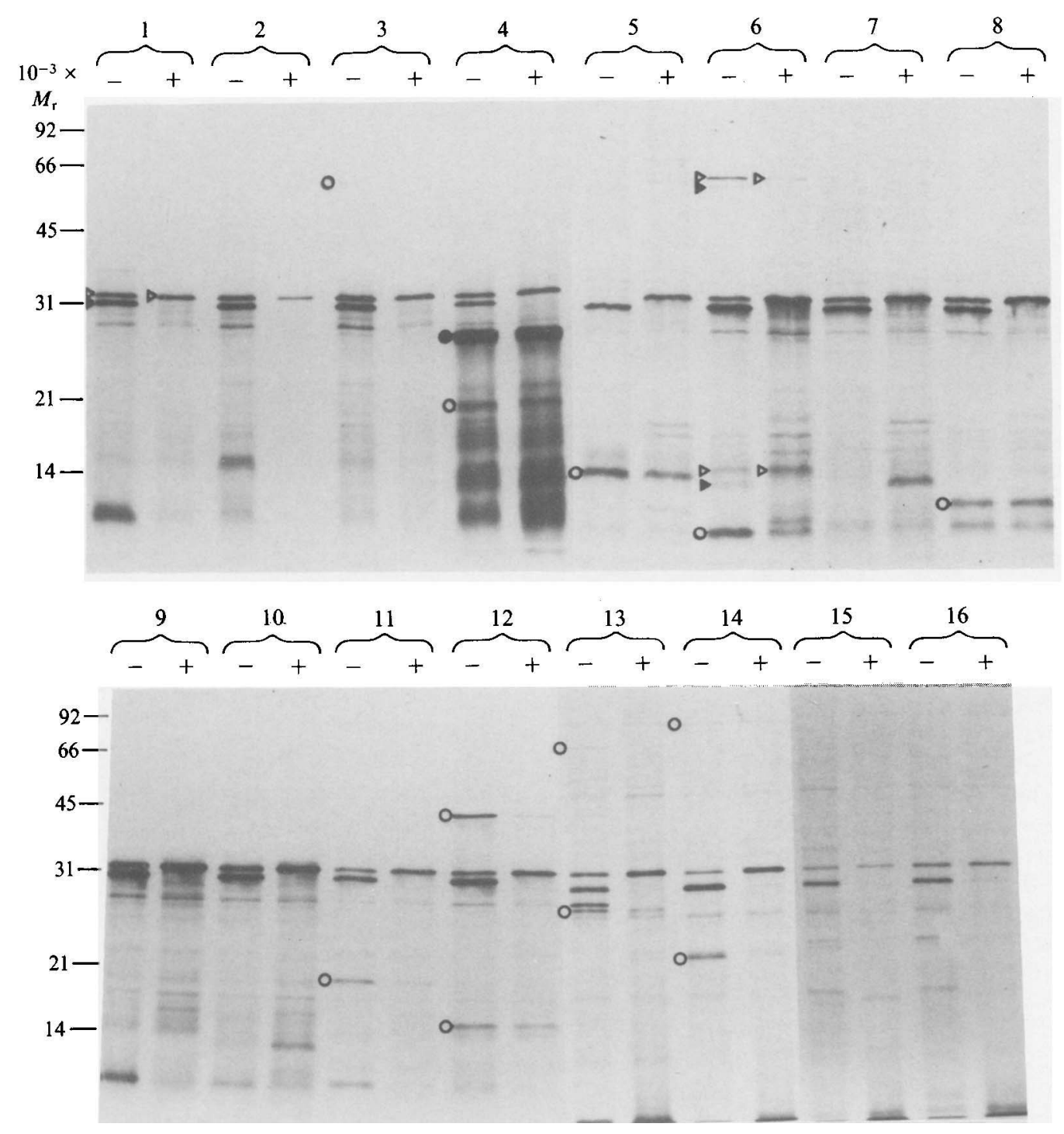

Fig. 4. Autoradiograms of $\left[{ }^{35}\right.$ S $]$ methionine-radiolabelled proteins resolved on $12 \cdot 5 \%$ SDS-PAGE gels. Labelled proteins were synthesized in $E$. coli minicells from recombinant plasmids containing $A$. salmonicida strain A449 plasmid DNA. Open circles indicate proteins encoded by $A$. salmonicida plasmid DNA. Experiments were done in the presence $(+)$ or absence $(-)$ of $10 \%$ ethanol. Open triangles indicate putative unprocessed or precursor forms of mature proteins (filled triangles) which predominate in samples labelled in the presence of $10 \%$ ethanol. The filled circle indicates a $25 \mathrm{kDa}$ chloramphenicol acetyltransferase. Lanes: 1, pBR322; 2, pEB15;3, pEB10;4, pEB3; 5, pEB7; 6, pEB2; 7, pEB9 ; 8, pEB8; 9, pEB11; 10, pEB12;11, pEB14; 12, pEB6; 13, pEB4; 14, pEB1; 15, pEB13; 16, pEB5.

almost completely prevented in the presence of ethanol. Western blotting experiments indicated that none of the expressed proteins were strong antigens when immunoblots were developed using antiserum raised to whole cells of strain A449 (data not shown). Another recombinant, pEB3, carrying a $7.5 \mathrm{~kb}$ insert (Fig. 4 , lane $4+/-$ ) appeared to overexpress a number of 
Table 4. Chloramphenicol acetyltransferase activity in cellular compartments of E. coli HB101(pBR322) and HB10I(pEB3) assayed by the spectrophotometric technique of Shaw (1975)

$\begin{array}{lcc}\text { Cellular compartment } & \overbrace{\mathrm{pBR} 322} & \mathrm{pEB} 3 \\ \left.\text { Cymol } \mathrm{min}^{-1} \text { (mg protein) }^{-1}\right]\end{array}$

tr, trace; -, no activity detected.

proteins, ranging in size from $M_{\mathrm{r}} 14000$ to $M_{\mathrm{r}} 25000$. This recombinant plasmid was shown to confer high-level chloramphenicol resistance (MIC $>500 \mathrm{mg} \mathrm{ml}^{-1}$ ) on the recipient strain. Further examination showed that the $M_{\mathrm{r}} 25000$ protein was restricted to the cytosolic compartment, and was a very active acetyltransferase when assayed using the spectrophotometric procedure of Shaw (1975) (Table 4).

\section{DISCUSSION}

This study has provided further genetic evidence for a taxonomic separation of 'atypical' and 'typical' strains of $A$. salmonicida. The differences in plasmid content of the two groups coincide with recent genomic DNA:DNA reassociation evidence that $\boldsymbol{A}$. salmonicida subsp. salmonicida is an extremely homogeneous taxon, while the 'atypical' strains are more diverse, but with distinct recognizable biotypes related to the fish species they were isolated from (Belland \& Trust, 1988). The plasmid content of 'atypical' $A$. salmonicida strains showed much greater diversity in plasmid DNA content than the conserved population of plasmids in 'typical' strains. Within the 'atypical' group there were distinct sub-groups based on plasmid content that correlated with the fish species and diseases from which the strains were isolated. Most notable were strains isolated from goldfish. Despite diverse geographical sources, all four isolates had three plasmids with similar $M_{\mathrm{r}}$ values. Two isolates, one from the USA, the other from Australia, had a fourth high- $M_{\mathrm{r}}$ plasmid. This apparent conservation of plasmid DNA may be due to an involvement of these plasmids in the pathogenesis of goldfish ulcer disease, and indicates a common source for the goldfish ulcer disease strains, at least in the case of the Arkansas and Australian isolates which were from goldfish stocks originating in Japan (Shotts et al., 1980; Whittington et al., 1987). Two other pairs of 'atypical' strains showed similar plasmid profiles. In one case, both isolates were from erythrodermatitis in European carp (Bootsma et al., 1977), and in the other case, both strains were isolated from marine fish species, i.e. sablefish and Pacific salmon (Evelyn, 1971), and Atlantic salmon. These results suggest that plasmid DNA content may be a useful epidemiological marker for 'atypical' $A$. salmonicida.

All 'typical' strains examined in this study contained at least four plasmid species. Using a genome size of $2.40 \times 10^{9} \mathrm{Da}$ (Belland \& Trust, 1988), plasmids represent approximately $20 \%$ of the $A$. salmonicida cellular DNA. The single large non-conjugative plasmid ( $>70 \mathrm{~kb}$ ) varied in size from strain to strain, but displayed considerable relatedness by restriction enzyme analysis. High- $M_{\mathrm{r}}$ conserved plasmids have been reported in a variety of other pathogens, including Yersinia enterocolitica (Portnoy et al., 1981), Salmonella typhimurium LT2 (Jones et al., 1982), Bacillus thuringiensis (Gonzales et al., 1981), Shigella sp. (Hale et al., 1983) and the fishpathogenic Yersinia ruckeri (De Grandis \& Stevenson, 1982) and Vibrio anguillarum (Crosa, 1980), and in all cases are important in pathogenesis. In this regard we have observed one strain of $A$. salmonicida (A451) from which two isolates with deletions in the large conserved plasmid have been found, and both display greatly reduced lethality in rainbow trout (unpublished data). To date, however, the phenotypic basis for this phenomenon has not been elucidated. 
A partially conserved plasmid of $6.0 \mathrm{~kb}$ was found in 10 of 14 'typical' isolates examined. This plasmid does not appear to be required for $A$. salmonicida virulence, as all strains lacking it (with the exception of A440 [ATCC 14174]) were fully virulent (Belland \& Trust, unpublished data). Indeed the $6.0 \mathrm{~kb}$ plasmid appears to have been lost from our isolate of A440 [ATCC 14174], and from the ATCC 14174 isolate studied by Hackett et al. (1984), as Toranzo et al. (1983) reported the presence of a $6.0 \mathrm{~kb}$ plasmid in their isolate of ATCC 14174. In contrast, our isolate of A440 [ATCC 14174] contained a $28 \mathrm{~kb}$ conjugative R-plasmid which was not seen in the other studies. Despite these conflicting data, it is not surprising that changes have occurred in this strain, which has been used as the archetypal $A$. salmonicida laboratory reference strain for over 20 years. Perhaps more surprising is the fact that despite decades of use as a laboratory strain, the plasmid profile is still very similar to that of recent isolates from nature.

The most remarkable conservation of plasmid DNA involved the three small plasmids pAsal, pAsa2 and pAsa3. These three high-copy-number plasmids (about 55 copies per cell; Hackett $e t$ al., 1984) were found in all 'typical' isolates examined despite their diverse geographical sources and isolation from a variety of fish species. Restriction enzyme analysis and protein expression assays showed that these plasmids were probably identical in all 'typical' strains. Small cryptic plasmids, generally very stable and found in high copy numbers, have also been found in a number of other bacterial species, including Neisseria gonorrhoeae (Korch et al., 1985), Shigella sonnei (Croft et al., 1983) and E. coli 15 (Cozzarelli et al., 1968). In each case however the conserved elements are single plasmids, in contrast to the group of three plasmids in $A$. salmonicida.

In cell-free transcription/translation lysates the three small conserved $A$. salmonicida plasmids (purified as a group) directed the synthesis of four proteins ranging in $M_{\mathrm{r}}$ from 25500 to 33300 . This seems a small number considering the coding capacity of $15.6 \mathrm{~kb}$ of plasmid DNA, but the overall efficiency of incorporation in our experiments was poor compared to controls of $E$. coli plasmid DNA. This may be due to a problem in either transcriptional or translational fidelity in an $E$. coli background. It is also important to note that estimates based on $\left.{ }^{35} S\right]$ methionine labelling can be low because some proteins contain few or no methionine residues (Glenn, 1976; Pollock \& Richmond, 1962).

Three of the 'typical' strains examined in the transcription/translation assays also possessed the $6.0 \mathrm{~kb}$ plasmid, and in each case a single new protein was apparent. In two strains, the protein had an apparent $M_{\mathrm{r}}$ of 34500 and in another an $M_{\mathrm{r}}$ of 33100 . The small plasmids isolated from 'atypical' strains were shown to code for different proteins than the pAsa plasmids when examined in the cell-free transcription/translation system. The $5.8 \mathrm{~kb}$ plasmid from 'atypical' strains A400 and A419 coded for four proteins ranging in $M_{\mathrm{r}}$ from 14000 to 34000 , while the $8.4 \mathrm{~kb}$ plasmid from strain A479 directed the synthesis of three proteins ranging in $M_{\mathrm{r}}$ from 14000 to 33300 . These results are in keeping with a similar expression of plasmid-encoded proteins from two small, conserved plasmids of Chlamydia trachomatis (pCTL2, $7 \cdot 3 \mathrm{~kb}$ ) and Chlamydia psittaci $(\mathrm{pCPMn}, 6 \cdot 2 \mathrm{~kb})$ which directed the expression of two $\left(M_{\mathrm{r}} 38000\right.$ and 48000$)$ and three $\left(M_{\mathrm{r}} 22000,38000\right.$ and 52000) proteins respectively (Joseph et al., 1986). Studies of very small, conserved plasmid DNA, such as pNZ500 $(1.5 \mathrm{~kb})$ in $S$. sonnei, have shown that these plasmids are totally reliant on the cellular machinery for replication, code for two or three proteins at most (involved in their mobilization by conjugative factors), and impart no phenotype on cells carrying them (Croft et al., 1983). The pAsa plasmids appear to be large enough to provide a definite but as yet unidentified phenotype. The pAsa plasmids also have the ability to be mobilized by conjugative plasmids (unpublished observation).

When expression of plasmid DNAs of a representative virulent 'typical' strain was examined using a minicell labelling system, at least 17 plasmid-encoded proteins were identified. Many plasmids in other species have been shown to code for exported proteins, including toxigenic enzymes (Elwell \& Shipley, 1980) and outer-membrane proteins (Elwell \& Shipley, 1980; Hale et al., 1983; Portnoy et al., 1981). Two of the plasmid-coded A. salmonicida proteins also appeared to be exported proteins because they contained peptide regions which resembled the leader sequences of exported proteins in that they were cleaved by $E$. coli cellular machinery only in the absence of $10 \%$ ethanol. However, neither of the pEB2-encoded export proteins co-purified with 
the outer membrane (unpublished observation), suggesting that they are either periplasmic constituents or are proteins exported across the outer membrane to the external medium. In this regard, Western blotting experiments indicated that none of the plasmid-coded $A$. salmonicida proteins were strong antigens.

One phenotypic property that was shown to be plasmid coded was the chloramphenicol resistance of strain A449. The $\mathrm{Cm}^{\mathrm{r}}$ phenotype is imparted by a chloramphenicol acetyltransferase (CAT) enzyme similar to those described by Gaffney et al. (1978). The $\mathrm{Cm}^{\mathrm{r}}$ gene must be carried by the high- $M_{\mathrm{r}}$ plasmid pAsa4 since the insert containing it is larger than any of the three low- $M_{\mathrm{r}}$ plasmids. Expression of the CAT gene in $E$. coli minicells was exceptionally high, and the CAT protein was the single predominant protein species in Coomassie-blue-stained wholecell lysates. It is not known whether this reflects a peculiar alignment of the CAT gene with adjacent pBR322 sequences, or whether the A. salmonicida CAT gene in pAsa4 itself has a high level of expression due to an unusual promotor or genetic arrangement. High levels of expression were not found for other $\boldsymbol{A}$. salmonicida plasmid genes examined.

The apparent universal carriage of plasmids by an obligate pathogen like $\boldsymbol{A}$. salmonicida, the stability of the plasmids, and the inability of workers to cure plasmids in 'typical' strains of the organism, points to an important role for the plasmids in the survival of $\boldsymbol{A}$. salmonicida. The ability to identify the products of $A$. salmonicida plasmid genes, as demonstrated in this study, will facilitate the directed generation of mutants in specific plasmid genes, and so increase our understanding of the role of plasmids in this important fish pathogen.

This work was funded, in part, by the Natural Sciences and Engineering Research Council (NSERC) of Canada. R. J. B. was the recipient of a NSERC Graduate Student Fellowship. We thank Yves Lobet and all those who sent us bacterial strains.

\section{REFERENCES}

Aoki, T., KitaO, T., ANDo, T. \& Arai, T. (1979). Incompatibility grouping of $\mathrm{R}$ plasmids detected in fish pathogenic bacteria, Aeromonas salmonicida. In Microbial Drug Resistance 2, pp. 219-222. Edited by S. Mitsuhashi. Baltimore: University Park Press.

Aoki, T., Mitoma, Y. \& Crosa, J. H. (1986). The characterization of a conjugative $\mathbf{R}$-plasmid isolated from Aeromonas salmonicida. Plasmid 16, 213-218.

Belland, R. J. \& Trust, T. J. (1988). DNA: DNA reassociation analysis of Aeromonas salmonicida. Journal of General Microbiology 134, 307-315.

BoOtsma, R., FiJan, N. \& BlommaerT, J. (1977). Isolation and preliminary identification of the causative agent of carp erythrodermatitis. Veterinary Archives 47, 291-302.

Cozzarelli, N. R., Kelly, R. B. \& Kornberg, A. (1968). A minute circular DNA from Escherichia coli 15. Proceedings of the National Academy of Sciences of the United States of America 60, 992-999.

Croft, J. E., Bergquist, P. L. \& Lane, D. (1983). A cryptic plasmid from Shigella sonnei. Journal of General Microbiology 129, 1513-1525.

Crosa, J. H. (1980). A plasmid associated with virulence in the marine fish pathogen Vibrio anguillarum specifies an iron-sequestering system. Nature, London 284, 566-568.

Curtiss, R., III (1981). Gene transfer. In Methodology for General Bacteriology, pp. 243-265. Edited by P. Gerhardt. Washington, DC: American Society for Microbiology.

De Grandis, S. \& Stevenson, R. M. W. (1982). Variations in plasmid profiles and growth characteristics of Yersinia ruckeri strains. FEMS Microbiology Letters 15, 199-202.
Dougan, G., Dowd, G. \& Kehoe, M. (1983). Organization of K88ac-encoded polypeptides in the Escherichia coli cell envelope: use of mini-cells and outer membrane protein mutants for studying assembly of pili. Journal of Bacteriology 153, 364370.

Elwell, L. P. \& Shipley, P. L. (1980). Plasmidmediated factors associated with virulence of bacteria to animals. Annual Review of Microbiology 34, 465-496.

EVELYN, T. P. T. (1971). An aberrant strain of the bacterial fish pathogen Aeromonas salmonicida isolated from a marine host, the sablefish (Anoplopoma fimbria), and from two species of cultured Pacific salmon. Journal of the Fisheries Research Board of Canada 28, 1629-1634.

Filip, C., Fletcher, G., Wulff, J. L. \& Earhart, C. F. (1973). Solubilisation of the cytoplasmic membrane of Escherichia coli by the ionic detergent sodium lauryl sarcosinate. Journal of Bacteriology 115, 717-722.

Gaffney, D. F., Foster, T. J. \& Shaw, W. V. (1978). Chloramphenicol acetyltransferase determined by $\mathbf{R}$ plasmids from Gram-negative bacteria. Journal of General Microbiology 109, 351-356.

GlenN, A. R. (1976). Production of extracellular proteins by bacteria. Annual Review of Microbiology 30, 41-62.

Gonzales, J. M., Dulmage, H. T. \& Carlton, B. C. (1981). Correlation between specific plasmids and delta-endotoxin production in Bacillus thuringiensis. Plasmid 5, 35I-365.

Hackett, J. L., Lynch, W. H., Paterson, W. D. \& Coombs, D. (1984). Extracellular protease, extracel- 
lular haemolysin, and virulence in Aeromonas salmonicida. Canadian Journal of Fisheries and Aquatic Sciences 41, 1354-1360.

Hale, T. L., Sansonetti, P. J., Schad, P. A., Austin, S. \& Formal, S. B. (1983). Characterization of virulence plasmids and plasmid-associated outer membrane proteins in Shigella flexneri, Shigella sonnei, and Escherichia coli. Infection and Immunity 40, 340-350.

Halegoua, S. \& InOuye, M. (1979). Translocation and assembly of outer membrane proteins of Escherichia coli. Selective accumulation of precursors and novel assembly intermediates caused by phenethyl alcohol. Journal of Molecular Biology 130, 39-61.

Hedges, R. W., Smith, P. \& Brazil, G. (1985). Resistance plasmids of aeromonads. Journal of General Microbiology 131, 2091-2095.

Ishiguro, E. E., AInsworth, T., KaY, W. W. \& TRUST, T. J. (1986). Heme requirement for growth of fastidious atypical strains of Aeromonas salmonicida. Applied and Environmental Microbiology 51, 668-670.

Ishiguro, E. E., KAY, W. W., AINSWORTh, T., Chamberlain, J., Buckley, J. T. \& Trust, T. J. (1981). Loss of virulence during culture of Aeromonas salmonicida at high temperature. Journal of Bacteriology 148, 333-340.

Jones, G. W., RABERT, D. K., SVINARICH, D. M. \& WhitfiELD, H. (1982). Association of adhesive, invasive, and virulent phenotypes of Salmonella typhimurium with autonomous 60 -megadalton plasmids. Infection and Immunity 38, 476-486.

Joseph, T., Nano, F. E., Garon, C. F. \& Caldwell, H. D. (1986). Molecular characterization of Chlamydia trachomatis and Chlamydia psittaci plasmids. Infection and Immunity 51, 699-703.

Kado, C. I. \& LiU, S. (1981). Rapid procedure for detection and isolation of large and small plasmids. Journal of Bacteriology 145, 1365-1373.

KaY, W. W., BuCKLeY, J. T., Ishiguro, E. E., Phipps, B. M., Monette, J. \& Trust, T. J. (1981). Purification and disposition of a surface protein associated with virulence of Aeromonas salmonicida. Journal of Bacteriology 147, 1077-1084.

KimurA, T. (1969). A new subspecies of Aeromonas salmonicida as an etiological agent of furunculosis on 'Sakuramascu' (Oncorhynchus masou) and pink salmon $(O$.gorbuscha): on the morphological and physiological properties. Fish Pathology 3, 34-44.

Korch, C., Hagblom, P., Ohman, H., Goransson, M. \& Normark, S. (1985). Cryptic plasmid of Neisseria gonorrhoeae: complete nucleotide sequence and genetic organization. Journal of Bacteriology 163, $430-438$.

LAEMMLI, U. K. (1970). Cleavage of structural proteins during the assembly of the head of bacteriophage T4. Nature, London 227, 680-685.

Maniatis, T., Fritsch, E. F. \& SAMbrook, J. (1982). Molecular Cloning: a Laboratory Manual. Cold Spring Harbor, NY: Cold Spring Harbor Laboratory.

MCCARTHY, D. H. (1978). A study of the taxonomic status of some bacteria currently assigned to the genus Aeromonas. PhD thesis, Council of National Academic Awards, Great Britain.
Palva, E. T., Hirst, T. R., Hardy, S. J. S., Holmgren, J. \& Randall, L. (1981). Synthesis of a precursor to the B subunit of heat-labile enterotoxin in Escherichia coli. Journal of Bacteriology 146, 325330

Paterson, W. D., Douey, D. \& Desautels, D. (1980). Isolation and identification of an atypical Aeromonas salmonicida strain causing epizootic losses among Atlantic salmon (Salmo salar) reared in a Nova Scotian hatchery. Canadian Journal of Fisheries and Aquatic Sciences 37, 2236-2241.

Pollock, M. R. \& Richmond, M. H. (1962). Low cysteine content of bacterial extracellular proteins: its possible physiological significance. Nature, London 194, 446-449.

Portnoy, D. A., Moseley, S. L. \& Falkow, S. (1981). Characterization of plasmids and plasmid-associated determinants of Yersinia enterocolitica pathogenesis. Infection and Immunity 31, 775-782.

SHAW, W. V. (1975). Chloramphenicol acetyltransferase from chloramphenicol-resistant bacteria. Methods in Enzymology 43, 737-755.

Shotts, E. B., Jr, Talkington, F. D., Elliot, D. G. \& MCCARTHY, D. H. (1980). Aetiology of an ulcerative disease in goldfish, Carassius auratus $(\mathrm{L})$ : characterization of the causative agent. Journal of Fish Diseases 3, 181-186.

SMITH, I. W. (1963). The classification of 'Bacterium salmonicida'. Journal of General Microbiology 33, 263274.

Toranzo, A. E., Barja, J. L., Colwell, R. R. \& HETRICK, F. M. (1983). Characterization of plasmids in bacterial fish pathogens. Infection and Immunity 39, 184-192.

Trust, T. J. (1986). Pathogenesis of infectious diseases of fish. Annual Review of Microbiology 40, 479-502.

Trust, T. J., Khouri, A. G., Austen, R. A. \& AsHBURNER, L. D. (1980). First isolation in Australia of atypical Aeromonas salmonicida. FEMS Microbiology Letters 9, 39-42.

UDEY, L. R. \& FRYER, J. L. (1978). Immunization of fish with bacterins of Aeromonas salmonicida. Marine Fisheries Review 40, 12-17.

Whittington, R. J., Gudkovs, N., Carrigan, M. J., AshbURNER, L. D. \& THURSTAN, S. J. (1987). Clinical, microbiological and epidemiological findings in recent outbreaks of goldfish ulcer due to atypical Aeromonas salmonicida in south-eastern Australia. Journal of Fish Diseases 10, 353-362.

Willis, R. C., Morris, R. G., Cirakoglu, C., SchellenberG, G. D., Gerber, N. H. \& Furlong, C. E. (1974). Preparation of periplasmic binding proteins from Salmonella typhimurium and Escherichia coli. Archives of Biochemistry and Biophysics 161, 64-75.

YANG, H. L., Ivanshikiv, L., Chen, H. Z., Zubay, G. \& CASHel, M. (1980). Cell-free coupled transcriptiontranslation system for investigation of linear DNA segments. Proceedings of the National Academy of Sciences of the United States of America 77, 7029. 7033. 